\title{
A SYSTEM FOR THE MANAGEMENT OF OLD BUILDING RETROFIT PROJECTS IN HISTORICAL CENTRES: THE CASE OF PORTUGAL
}

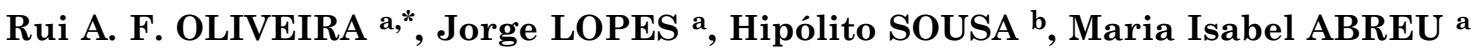 \\ ${ }^{a}$ Department of Construction and Planning, Polytechnic Institute of Bragança, Campus de Santa Apolonia, \\ Bragança 5300-253, Portugal \\ ${ }^{b}$ Department of Civil Engineering, Faculty of Engineering of O'Porto University, Rua Dr. Roberto Frias, \\ Porto 4200-465, Portugal
}

Received 28 December 2015; accepted 26 April 2016

\begin{abstract}
The retrofitting works in old buildings require appropriate knowledge of the vernacular techniques. Previous researches have identified retrofitting works as more intrusive and using more unnecessary demolition materials than real needs. This study constitutes a new framework that focuses on the project management success of old building retrofitting in historical centres by developing a methodological system for this purpose. It uses a construction sector system approach, reviews legal requirements, framework specifications, recommendation practices and sustainable measures adapted to old building projects. It presents 50 parameters adapted to these works' specificities that could be used by construction market stakeholders. The research uses a case study methodology divided in two parts. The first one involves the review of building retrofitting projects in historical centres, complemented by a questionnaire in the second part. The results of the projects review have shown little concern with the underlying sustainability aspects of retrofitting works in all project designs analysed. However, the questionnaire results have revealed a high interest and applicability of all parameters omitted in the project designs data. The study describes a useful management system in a toolkit format which might contribute to reduce uncertainty in the management of retrofitting projects in historical centres.
\end{abstract}

KEYWORDS: Retrofitting works; Project management; Old buildings; Project design; Sustainability

\section{INTRODUCTION}

Revitalisation and renovation of historical centres contribute to sustainable development as these areas contain conditions to fulfil daily needs such as leisure, education, business, services and other activities (Balsas 2004). Historical centres can reflect a harmonious social balance, using a range of activities to become a favourable environment for social integration (UNESCO 2014). Nowadays, some historical centres are not being used for economic purposes as much as before and are not well adapted to the demands of industry and new markets (Pickard 2001). The Council of the European Union (2014) recognizes cultural heritage as resources inherited and non-renewable with important economic and social impacts and contributes to environmental sustainability. According to European Commission (2014), in historic cities a wise heritage management can be successful and

* Corresponding author. E-mail: roliveira@ipb.pt sustainable, "through the energy-efficient re-use of historic buildings, and the promotion of greener transport and cultural tourism".

However, historical centres are sought for touristic purposes due to their configuration, architecture, unicity and artistic richness, which does not occur in the peripheral built areas (Balsas 2004). Most historical centres present problems regarding buildings deterioration, habitability conditions, gentrification, dereliction and real estate speculation, among others. Examples of problems concerning retrofitting include the existing constraints, cultural and patrimonial aspects, real estate market pressures, demolition of elements which could otherwise be reutilised (Ferretti et al. 2014), lack of parking spaces, flaws in planning not adjusted to real needs, increase of delays and costs, among others. According to Decree-law 309/2009, a building could have relevant cultural interest in historic, paleontological, archeological, 
architectonic, artistic, ethnography, scientific, social, industrial or technical and these must be demonstrate, separately or jointly, memory values, antique, authenticity, originality, rarity, uniqueness or exemplary. The cultural heritage involves a complex process of interdisciplinary approach values such as identity, authenticity, integrity, exemplarity, originality, oldest and many others recognized as cultural ones to preserve in collective memory and our history (Mazzanti 2002). Portugal has 5.9 million residential units and $17 \%$ of them are old with vernacular characteristics before the advent of reinforced concrete building. A half of Portuguese old buildings, including those in historical centres, are in an advanced stage of degradation and lacking regular maintenance. The Government has been devising a set of legislative measures to stimulate and develop the retrofit market segment but without success. However, the buildings located in historical centres which are in good conditions can be improved through lighter, less costly actions and could be more attractive in quality and sustainability conditions than new ones. Also, the best opportunity to improve energy efficiency would be during building retrofit actions (Asadi et al. 2012; Dall'O et al. 2012). The demand for buildings to retrofit obeys a very specific market, which sometimes does not help in the retrofitting process development and the subsequent improvement of the surrounding areas (Volvačiovas et al. 2013). There are some trends of building retrofitting at low costs (low-cost retrofitting, controlled costs) for leasing or targeting specific market segments. Within this context, this work is intended to aid different stakeholders in old building retrofitting with regard to the underlying technical aspects, bringing to light possible causes and consequences (Ma et al. 2012), and to contribute to the decision making process (Olander, Landin 2005). According to Henriques et al. (2015), "the highest direct and indirect job generation potential can be obtained in the solutions that optimise renovation investments" and "the optimisation of retrofitting investment allows reaching high, albeit realistic, values both for GDP and the employment level".

The purpose of this article is to present a toolkit "Retrofitting management system for buildings located in consolidated urban areas", hereafter called "management system". This system consists of a methodology in a toolkit format which encompasses constraints, regulatory legal provisions, technical recommendations and sustainable practices applicable to the retrofitting of old building.
The type of protection regime can influence the development of the construction process. Monuments conservation and restoration requires a kind of construction practice that applies techniques that preserve the identity and authenticity of old buildings. Thus this management system is aimed at building retrofit projects located in historical centres and old building retrofitting in general. It is not suitable for interventions in buildings classified as monuments which have specific protection regimes. The remaining of this paper is structured as follows. Section 2 describes the research methodology followed in the study and formulates the hypothesis. The thematic areas used for the management system such as old building constraints, best practices and sustainable technical solutions applied for old buildings are presented in Section 3. Section 4 contains the management system structure such as parameters, valorisation criteria parameters and the results of an opinion survey. Section 5 describes an extended case study with two complementary sources of data (a review of old building project designs and interviews supported by questionnaire) and the formulated hypothesis is tested. Section 6 presents the main conclusions of the study.

\section{RESEARCH METHODOLOGY}

This research follows an exploratory qualitative approach, based on a generalisation process in which empirical data is used to create a theory or a model (Yin 2005). The methodology followed has a dynamic nature, enabling adjustments throughout the research process so that the appropriacy of the research methods is more adjusted to the data and the results. According to Fellows and Liu (2008), exploratory research has a nature that enables to research on phenomena, identify variables, formulate hypothesis for other research works, with empirical formulation applicable to case studies and field works, allowing the use of data from observation, interviews, questionnaires, desk review (reports, archives, projects). The research process followed in this study is schematised in Figure 1.

This study begins with a bibliographic review, authors' experience and knowhow regarding old building retrofitting in order to identify problems and needs in the management of this type of works (Mahmood et al. 2012). Although retrofitting works are conditioned and hindered by constraints inherent to these works, they integrate legal provisions, technical recommendations and solutions that pro- 


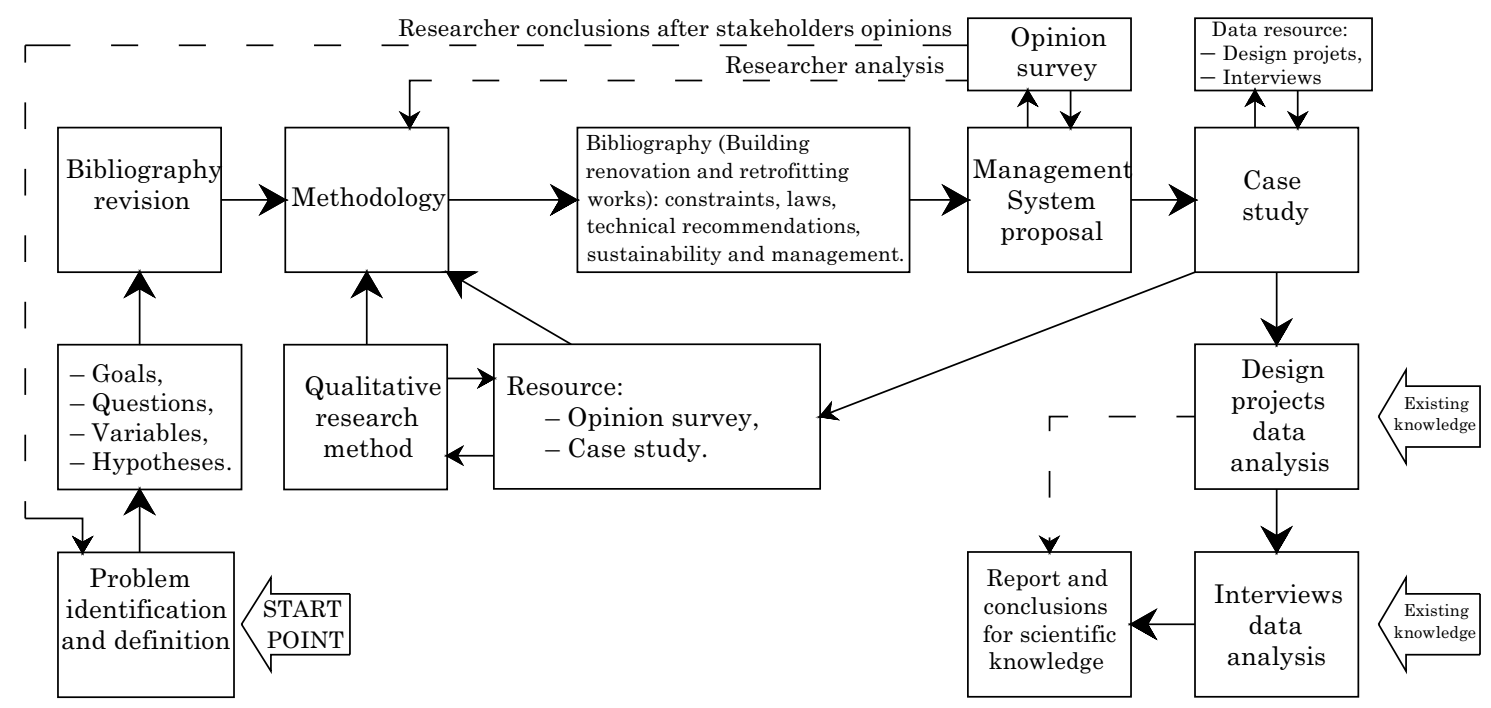

Fig. 1. Research methodology (adapted from Fellows, Liu 2008)

mote sustainability. The hypothesis is thus formulated as follows:

- "The project designs of old buildings are made with conventional solutions without considering sustainability principles. Stakeholders' decisions must be more supported by practices that consider regulations, constraints, retrofitting best practices and sustainable solutions".

In order to test the hypothesis, a management system consisting of 50 parameters was devised (see section 4.2). All the management system parameters consider possible thematic aspects about project management practices, including time and cost overruns. The parameters were submitted to an opinion survey with the aim to ascertain their relevance and usefulness for stakeholders in the retrofitting segment of the construction market. Each parameter was developed attending possible comparison between conventional practices and other practices considered more sustainably suitable to retrofitting works.

The research used a case study methodology divided in two different parts. The first one involved the review of building retrofit project designs located in the protection regime of O'Porto's historical centre. The second part of the case study consists of interviews guided by a questionnaire with knowledgeable professionals in the building retrofitting area. The review of the project designs would ascertain whether retrofitting practices are more appropriate for recent buildings and, thus, less suited for existing buildings previous to reinforced concrete generalisation. The main goal was to find convergence between the information contained in the project designs with the contents of the management system parameters. In the second stage, the interviews would seek the relevance of the management system parameters that are omitted in the project designs. This second stage case study was supported by some statistical tests, the Cochran Q test (testing the difference between paired proportions) and the Cronbach's alpha test (internal consistency test). The minimal limit required for Cronbach's alpha above 0.60 (Hair et al. 2003) and Cochran $Q$ test must demonstrate responses proportion with significant difference. If all 50 parameters of the management system are considered relevant and with interest by the results of the case study, than the hypothesis may be accepted. In that case, the parameters will be considered useful and with interest for old building retrofit projects located in the protection regimes of historical centres.

\section{THEMATIC AREAS USED IN THE CONSTRUCTION OF THE MANAGEMENT SYSTEM}

\subsection{Diagram of the management system}

Retrofitting works involve recycling policies management (reutilization, reuse, recycling, recover, renovate) (Ma et al. 2012; Wang, Zeng 2010), lean construction practices (Koskela et al. 2002) and maintaining building originality as possible. The management system was structured considering the thematic context contained in the hypothesis formulated, thus being structured with 50 parameters. Each parameter integrates technical aspects and factors supporting the decision-making from stakeholders, constraints, good retrofitting 


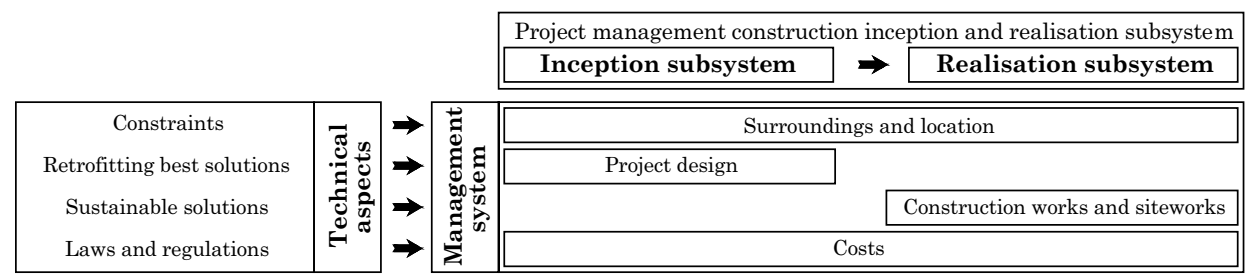

Fig. 2. Organizational diagram of the management system

practices, sustainable solutions and legal requirements, Figure 2.

\subsection{A construction project management system}

All construction works are building during a short period of time under the influence of some aspects: information, energy, materials, policies, legal and institutional system, society, technology and economy. There are many other institutional factors namely, construction regulations, products and services certification, construction permits and standards. Besides, Gudienè et al. $(2013,2014)$ describes a set of critical success factors for construction management, divided in five different groups, such as: Project; Project managers; Project management/team members; Contractor (construction companies); Client. Each group of factors is connected between themselves and could influence several variables from another group.

According to Carassus et al. (2006), a "project management and on site production are provided by services firms dealing with briefing, design, technical studies, co-ordination, control and by construction firms involved in new construction, major repairs, refurbishment and demolition works". There are also several legal regulations about safety and health practices, environment, governmental agencies and others without legal regulations like "lobbies" or individual citizens. These factors could influence the project management success and the promoter's decisions (Parfitt, Sanvido 1993; Jha, Iyer 2006; Dutta, Husain 2009). Walker (2007) defines a model of the construction process divided in 3 subsystems, conception, inception and realisation. The conception subsystem is connected to an initial idea and viability hypothesis. The acquisi- tion of real property choice implies the inception subsystem, Figure 3.

The inception subsystem studies all building market possibilities such as: buy or lease an existing building, construction a new building or adapt an owned existing building. If the option is to build a new building or adapt an owned existing building then the realisation subsystem is required. In realisation phase, a project design is developed, followed by construction works according to client needs and legal regulations. The model of the construction process has a connection with buildings life cycle analysis, namely: viability, planning and design, realisation (construction or retrofit works), adapting and selling (warranty, use, maintenance, conservation and deconstruction) (Thabrew et al. 2009). The management system used in this research work follows the assumption that there is an intervention on an existing building (inception) with retrofitting works and design needs (realisation), Figure 2 and 3.

\subsection{Constraints to old building retrofitting in historical centres}

Retrofitting works consist of a set of actions to improve performance (Iwaro et al. 2014) and comfort levels. However, all old buildings in historical centres have constraints and risks (Marco, Thaheem 2014) which must be planned before any works, such as (Hatush, Skitmore 1997; Geoghegan, Dulewicz 2008):

- Protection regimes for proclaimed monuments and sites.

- Surroundings and location - unmatched places (buildings proximity, gradients and access width), lacking sanitary and comfort conditions, labelled as unappealing.

- Project Design - Difficulties related to the diagnosis and characterisation of the existing building, structural vulnerability and

\begin{tabular}{ll|l|l|} 
CONCEPTION & INCEPTION \\
$\begin{array}{ll}\text { - Contribution to objective by } \\
\text { the acquisition of real property } \\
\text { - Other alternatives not requ ired } \\
\text { the acquisition of real property }\end{array} \longrightarrow$ - Construction a new building \\
- Adapt an owned existing building & $\begin{array}{l}\text { - Buy an existing building } \\
\text { - Lease an existing building }\end{array}$
\end{tabular}

Fig. 3. Project management phases for acquisition of real property 
limitations regarding the space functionalities. Norms and construction laws are directed towards new construction works, with a reflection on the quality of the project design and interventions maladjusted to the real needs.

- Construction works and site works - Planning out-of-step with reality, with low risk weighing in the conception phase. Low level of communication between stakeholders. Costly interventions with large quantities of labour and slow pace of work. Making use of specialised subcontracting companies, without a special regime for retrofitting companies or specialised technical monitoring, thus making it difficult the application of the work health and safety laws.

- Costs - Difficult quantification of exact costs, with constraints regarding taxes, tax concession and incentive mechanisms, encumbrances, real estate speculation.

\subsection{Best practices in old building retrofitting in historical centres}

Building retrofitting involves the reutilization of available resources, the resolution of anomalies, improvement of performance and quality and comfort levels in buildings (Mazzarella 2015). It is advisable to use appropriate diagnostic procedures by quantitative approach, performance levels and structural efficiency (Sorace, Terenzi 2013; Rosenfeld, Shohet 1999). In order to preserve buildings authenticity, ICOMOS (2003) recommends best practices for retrofitting works, such as:

- To reduce retrofitting works at minimum levels, replacing degraded parts;

- To apply reinforced structures and solutions to maintain original techniques as far as possible;

- To use materials requiring compatibility and reversibility and reuse them in future (deconstruction);

- To improve buildings performance and comfort levels, such as applying solutions to energy efficiency, water efficiency, acoustic comfort, natural lighting and adapt existing regulations;

- To implement monitoring policies and plans for conservation and maintenance works;

- To develop project designs compatible with retrofitting works and planned by a multidisciplinary design team.

\subsection{Sustainable technical solutions in old building retrofitting in historical centres}

The sustainable development requires a balanced analysis in social, economic and environment dimensions of sustainability, including the construction sector impacts (Srdić, Šelih 2011; Henriques et al. 2015). Retrofitting is a sustainable practice

Table 1. Implementation of building sustainable solutions

\begin{tabular}{|c|c|}
\hline Solutions & Description \\
\hline Retrofitting levels & $\begin{array}{l}\text { Deeper retrofitting enables the implementation of more generalised solutions regarding struc- } \\
\text { tural reinforcement, thermal, energy, water and acoustics }\end{array}$ \\
\hline Surrounding area & $\begin{array}{l}\text { Systems for harvesting rainwater coming from roofs and sealed areas; creation of green areas, } \\
\text { vegetable gardens; incentives to composting }\end{array}$ \\
\hline Central systems & $\begin{array}{l}\text { Sanitary water and space heating using solar collectors and additional support integrated in cen- } \\
\text { tralised systems }\end{array}$ \\
\hline $\begin{array}{l}\text { Passive solar } \\
\text { technology }\end{array}$ & $\begin{array}{l}\text { Solutions with direct solar gain through façade and roof openings, greenhouse effect, heat storage } \\
\text { walls, air convection circuit }\end{array}$ \\
\hline Passive cooling & $\begin{array}{l}\text { Include passive cooling solutions with air intake in the building lower parts and air outlet on the } \\
\text { roof (thermal circulation) }\end{array}$ \\
\hline Natural light & Use of natural light; adoption of light colours, multifunctional open spaces \\
\hline Materials & $\begin{array}{l}\text { Reutilization of materials and replacement of the degraded materials by similar ones; use of ma- } \\
\text { terials allowing reversibility and deconstruction, with recycled contents of low impact on water, } \\
\text { energy, emissions, transport, maintenance and elimination }\end{array}$ \\
\hline $\begin{array}{l}\text { Construction } \\
\text { technologies }\end{array}$ & $\begin{array}{l}\text { Reutilization of existing structural materials and technologies so as to maximise resources, re- } \\
\text { duce demolition wastes, increase economic savings and maintain authenticity }\end{array}$ \\
\hline Electrical appliances & More efficient electrical appliances \\
\hline Water & Integrated solutions for the reutilization of rainwater and wastewater \\
\hline Energy & $\begin{array}{l}\text { Energy production from renewable sources (photovoltaic panels not visible from the street); fol- } \\
\text { lowing the nearly zero energy building (NZEB) issue; efficient lighting }\end{array}$ \\
\hline Thermal & Energetic certification, preserving heritage architecture (authenticity) \\
\hline Monitorization & Implementation of energy and water consumption monitoring systems \\
\hline Maintenance & Development of conservation and maintenance plans and records \\
\hline Manual Guide & Development of the building user manual \\
\hline Sustainability & Possibility of certification of the building sustainability assessment \\
\hline
\end{tabular}


and applying it at a city, street or block scale has more environmental and economic benefits than at a building scale (Dall'O et al. 2012). In terms of energy, according to study developed by Balin and Baraçli (2015), the best renewable energy alternative was the wind energy, followed up by solar, hydraulic, biomass, geothermal, and hydrogen energy. However, in historic centres the wind energy equipment could cause landscaping disturbance. Solar energy equipment could be used in buildings roofs at South orientation and not visible from the streets, which contribute to historical centre preservation image.

Methods that enable the assessment of buildings taking into account sustainability principles have been developed. Such methods include: CEEQUAL, BREEAM, LEED, NABERS, BEPAC, HQE, CASBEE, SBTool, LiderA, among others (Todd et al. 2001; Medineckiene et al. 2015). Sustainable solutions are more appropriate when implemented in the design phase (Russell-Smith, Lepech 2015; Ochoa, Capeluto 2015). Table 1 addresses the common contents of the methods BREEAM, HQE, LEED, LiderA and SBToolPT, which are transversal in terms of energy saving (Ferreira et al. 2014; Østergård et al. 2016), ozone layer protection and resources reutilization (Lewis et al. 2015).

\section{MANAGEMENT SYSTEM STRUCTURE}

\subsection{Opinion survey with interviews supported by questionnaire}

The contents of the management system were developed from literature review, and the opinions of construction professionals with expertise in building retrofitting. There are some methods and guidelines which were reviewed for the development of the management system, such as: Construction Management System (Walker 2007), RENO-EVALUE (Jensen, Maslesa 2015), method for evaluation of renovation projects (Morelli et al. 2014), IFORE (Innovation for Renewal) proposals (Sdei et al. 2015), Building EQ - Guidelines for the Evaluation of Building Performance (BuildingEQ 2008), Building Information Modelling models. Furthermore, the management system was submitted to an opinion survey conducted according to the structure of a pilot study (Yin 2005), aiming to consolidate and dissipate possible divergences (Cerreta et al. 2012). The opinion survey was conducted by means of interviews guided by a questionnaire, directed at 7 construction professionals ( 2 architects, 4 engineers and 1 conservation and restoration professional) who practise their activity in building retrofitting and in building maintenance works. The interviewees considered that the management system is applicable, contains relevant issues and is well-organised. Some responses revealed some subjectivity among some interviewees, who seemed to give responses biased at their own professional area, thus making it difficult to reach unanimity in some issues. When revising the management system, all the recommendations received were followed, but it is worth highlighting the following ones:

- Architectural freedom of expression preserving the authenticity of acknowledged cultural values.

- Inclusion of the possibility to integrate recycled and recyclable materials with environmental benefits.

- In restoration, choosing more environmentally friendly chemical products than the conventional ones.

- Preference for local workforce, local and traditional construction materials.

- Valuing buildings touristic potential, choosing appropriate energy production solutions.

\subsection{The parameters of the management system}

The management system is structured in 4 main areas (Surroundings and location; Conception Project design; Construction works and site works; Costs) which converge with the assumptions of the formulated hypothesis (Oliveira 2013). The opinion survey contribution and their recommendations were also considered in the thematic contents of the management system. These 4 areas consist of 15 indicators with 50 thematic parameters encompassing strategies (Menassa 2011; Dutta, Husain 2009), solutions for constraints, best practices used in building retrofitting and legal requirements (Fig. 2). The parameters are grouped as shown in Table 2.

\subsection{Valorisation criteria of the management system parameters}

Each parameter of the management system has a thematic description and provides goals that contain five different valorisation criteria, organized from E (Less Sustainable) to A (More Sustainable). The valorisation criteria $\mathrm{D}$ are considered to be conventional practices and without any sustainable benefits growth. The organization is made by steps and goals according to the importance and 
Table 2. Management system thematic areas, indicators and parameters

\begin{tabular}{|c|c|c|}
\hline AREA & Indicators description & Parameters description \\
\hline \multirow{11}{*}{$\begin{array}{l}\text { A1. Surroundings } \\
\text { and location }\end{array}$} & \multirow[t]{3}{*}{ I1. Mobility and amenities } & P01. Public transport \\
\hline & & P02. Car parking \\
\hline & & P03. Local amenities \\
\hline & \multirow[t]{3}{*}{ I2. Local infrastructures } & P04. Outward firefighting means \\
\hline & & P05. Technical networks in public space \\
\hline & & P06. Urban space quality \\
\hline & \multirow[t]{3}{*}{ I3. Land use occupation } & P07. Land occupation \\
\hline & & P08. Total area and deployment area \\
\hline & & P09. Gardens and leisure places \\
\hline & \multirow{2}{*}{$\begin{array}{l}\text { I4. Solar orientation and } \\
\text { exposure }\end{array}$} & P10. Solar exposure \\
\hline & & P11. Solar orientation \\
\hline \multirow[t]{20}{*}{ A2. Project design } & \multirow{3}{*}{$\begin{array}{l}\text { I5. Characterization of } \\
\text { building conditions }\end{array}$} & P12. Request for technical studies \\
\hline & & P13. Characterization diagnoses of building conservation status \\
\hline & & P14. Project Design specificities \\
\hline & \multirow{3}{*}{$\begin{array}{l}\text { I6. Architectonic } \\
\text { organization and salubrity }\end{array}$} & P15. Conceptual architecture configuration and adaptability \\
\hline & & P16. Ratio useful floor area/Gross lettable area (GLA) \\
\hline & & P17. Acoustic insulation and indoor air quality \\
\hline & \multirow{4}{*}{$\begin{array}{l}\text { I7. Infrastructures, } \\
\text { foundations and structural } \\
\text { elements conditions }\end{array}$} & P18. Building technical networks \\
\hline & & P19. Peripheral retaining structures \\
\hline & & P20. Foundations \\
\hline & & P21. Structural elements \\
\hline & \multirow[t]{3}{*}{ I8. Materials } & P22. Materials reuse \\
\hline & & P23. New materials \\
\hline & & P24. Fire safety \\
\hline & \multirow[t]{7}{*}{ I9. Sustainability promotion } & P25. Water recovery and reuse \\
\hline & & P26. Solar collectors for hot water production \\
\hline & & P27. Electrical energy production \\
\hline & & P28. Energetic efficiency in thermal comfort \\
\hline & & P29. Other solutions for energetic efficiency \\
\hline & & P30. Bioclimatic solutions \\
\hline & & P31. Other sustainable solutions \\
\hline \multirow{15}{*}{$\begin{array}{l}\text { A3. Construction } \\
\text { works and site } \\
\text { works }\end{array}$} & \multirow{4}{*}{$\begin{array}{l}\text { I10. Initial works } \\
\text { constraints }\end{array}$} & P32. Site works and surrounding space \\
\hline & & P33. Adjoining building conservation state \\
\hline & & $\begin{array}{l}\text { P34. Stabilization and consolidation of building works and adjoining } \\
\text { buildings }\end{array}$ \\
\hline & & P35. Adjoining buildings waterproofing \\
\hline & \multirow{4}{*}{$\begin{array}{l}\text { I11. Industrialization/ } \\
\text { execution of works }\end{array}$} & P36. Workforce \\
\hline & & P37. Specialized workforce and company's technical capacities \\
\hline & & P38. Specialized subcontracts \\
\hline & & P39. Technical requirements monitoring \\
\hline & \multirow{4}{*}{$\begin{array}{l}\text { I12. Risk and constraints } \\
\text { potential }\end{array}$} & P40. Propensity to project design changes \\
\hline & & P41. Propensity to the occurrence of unexpected works \\
\hline & & P42. Propensity to time overruns \\
\hline & & P43. Propensity to other work constraints \\
\hline & \multirow{3}{*}{$\begin{array}{l}\text { I13. Other features resulting } \\
\text { from works }\end{array}$} & P44. Archaeological Works prospection \\
\hline & & P45. Construction and demolition waste management \\
\hline & & P46. Needs of occupant's relocation \\
\hline \multirow[t]{4}{*}{ A4. Costs } & \multirow[t]{2}{*}{ I14. Work costs } & P47. Costs of urban space works \\
\hline & & P48. Costs of general building works \\
\hline & \multirow{2}{*}{$\begin{array}{l}\text { I15. Tax incentives and } \\
\text { other costs }\end{array}$} & P49. Possibility to apply for benefits and tax incentives \\
\hline & & P50. Maintenance and conservation strategies \\
\hline
\end{tabular}


Table 3. Thematic description and valorisation criteria of the parameter P05 - Technical networks in public space

\begin{tabular}{ll}
\hline Goals & $\begin{array}{l}\text { The parameter values the existence and modernity of public space technical networks, namely water sup- } \\
\text { ply, wastewater drainage, rainwater drainage, electricity, telecommunications, gas supply, excluding ex- } \\
\text { ternal fire-fighting equipment described in parameter P04 }\end{array}$ \\
\hline $\begin{array}{l}\text { Valorisation } \\
\text { criteria }\end{array}$ & E (less sustainable) - some public networks are non-existent \\
& D (conventional) - existence of public networks that needs general renovation \\
& C - existence of public networks although less than $50 \%$ of them are new or had recent renovation \\
& B - existence of public networks and more than 50\% of them are new or had recent renovation. The major- \\
& ity of them are accessed by galleries or other solutions without demolition works \\
& A (more sustainable) - all public networks are new or have recent renovation works, being accessible by \\
galleries or another kind of solutions without demolition works
\end{tabular}

the sustainable benefits (Mulliner et al. 2013), which were supported by the results of the opinion survey. Each criterion analyses a set of different information: technical aspects supported by each thematic area, namely constraints aspects, sustainable solutions, retrofitting best practices, construction laws and regulations into force. Table 3 represents an example of goals and valorisation criteria presented in the parameter P05 contents.

\section{CASE STUDY}

\subsection{Initial considerations of the case study}

This research work involves an extended case study with 2 complementary sources of data: old building retrofit project designs and interviews supported by a questionnaire (Oliveira 2013). The questionnaires were carried out after the compilation of the desk review results and the convergence of the results with the formulated aims was assessed.

\subsection{Case study first phase - desk review of building retrofit project designs}

This stage involved an analysis of 7 project designs located in the historical centre of O'Porto and they were assigned by the Society of Urban Rehabilitation of O'Porto, in which one of the main goals is to refurbish the buildings and structures of the city centre. The historical centre of O'Porto is classified as UNESCO World Heritage site since 1996. One of the project designs was dated 2001, four were from 2007 and two from 2011 . Only 5 of the 7 project designs had their works concluded in 2013 , the date of the conduction of this case study and were approved by the municipalities. The documents analysed consist of architectural designs and speciality designs including stability, water supply, wastewater drainage, rainwater drainage, thermal, acoustic, gas supply, buildings fire safety, telecommunications, electricity, and also the contract documents, technical specifications, health and safety plans, construction and demolition waste management and bill of quantities. Each analysis has established convergence between the project designs information and the contents of each parameter of the management system. Every result is encompassed within one of the following types of response:

- "a" - Not referred to in the project design;

- "b" - Referred to in the project design;

- "c" - Not referred to in the project design but possible to obtain through in situ analysis.

Some results were conditioned by the lack of information in the project designs since not all the documents requested were provided for analysis. Figure 4 shows the convergence of the information collected in project designs with the contents of the 50 parameters of the management system.

The results show that the project designs are similar to those of new constructions, showing responses of type "b" ranging between 22 parameters (44\%) in project design 2 to 26 parameters $(52 \%)$ in project design 6 . Omitted information in the project designs (type "a" response) varies between a minimum of 9 omitted parameters (18\%) in project designs 5, 6 and 7, and a maximum of 13 parameters $(26 \%)$ in project designs 2 and 3 . The parameters not referred in the project but possible to obtain through in situ analysis (type "c") range

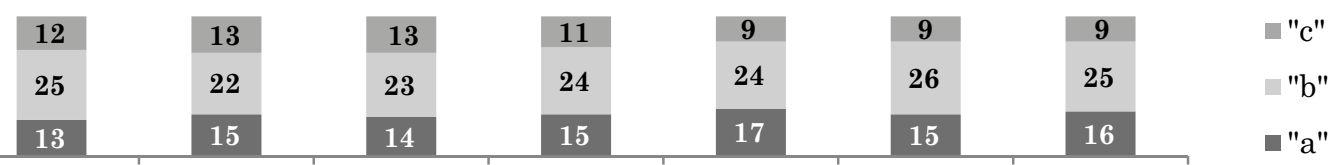

Proj. Design 1 Proj. Design 2 Proj. Design 3 Proj. Design 4 Proj. Design 5 Proj. Design 6 Proj. Design 7

Fig. 4. Information obtained per project design analysed 
from $13(26 \%)$ in project design 1 to 17 (34\%) in project design 5 . The projects design documents which were provided for analysis enabled us to assess responses in parameters P05, P07, P08, P11 to P16, P18 to P22, P24, P29, P32, P40 to P42 and $\mathrm{P} 45$. Positive responses with the projects were obtained in $71.4 \%$ for parameters P13, P24, P29 and $\mathrm{P} 32$, in $85.7 \%$ for parameter P05 and in $100 \%$ for the remaining parameters mentioned above. However, since not all the elements of the project were provided, the research did not have the necessary information to establish a connection with parameters P04, P10, P17, P26 to P28 and P48, despite the fact that some of them address obligatory issues. Therefore, the study enabled us to obtain a percentage of $42 \%$ of the parameters converging with the data collected from the projects, although such convergence would have been possible in $56 \%$ of the parameters if all the elements of the project had been provided. Besides the parameters mentioned above, parameters P04, P10, P17, P26 to P28, P48 would also be present. This study shows that the information in the project designs did not contemplate 22 (44\%) out of the total 50 parameters of the management system. The analyses of all project designs have also shown that the 28 parameters are attended by legal requirements.

Therefore, the thematic areas of the 22 parameters with omitted or not converging information in the analysed project designs involve parameters P01 to P03, P06, P09, P23, P25, P30, P31, P33 to P39, P43, P44, P46, P47, P49 and P50. The project designs do not contain information related to the surroundings, public transport, parking, amenities, urban space quality, green areas, leisure and entertainment areas, and also aspects regarding sustainability and quality of life. It is important to address and manage these issues when performing retrofitting works. Other omitted information's are environmental concerns and novel materials, bioclimatic solutions, water reutilization, among others. Following the same line, it is not frequent to find management information regarding the need for intervention in adjoining buildings, which is paramount to the reduction of damage in such buildings. Information regarding planning is also overlooked, namely a quantification of labour, pace of work, specialised resources, technical capacity of the companies involved and technical monitoring needs, although all these are important for the success of the project (Chan et al. 2002; Ahadzie et al. 2008; Niu et al. 2010; Parfitt, Sanvido 1993). Also absent from the analysed project designs are information regarding costs of intervention in ur- ban areas, of maintenance period and the attribution of eventual tax benefits or incentives under the law into force.

\subsection{Case study second phase - interviews guided by questionnaire}

The results obtained in the first phase of the case study show that the project designs use common solutions and do not take into account sustainability principles and that the interventions do not bear in mind the specificities of each retrofit work. However, the hypothesis conveys that stakeholders must be given greater support through practices that the same hypothesis considers to be contained in the management system. Therefore, it is important to assess the relevance of the 22 omitted parameters (section 5.2). Thus, the second part of the case study was developed to complement the first one and to assess the contribution of these 22 parameters to the success of old building projects. Particularly, the second phase of the study involved the administration of 15 interviews structured with a supporting questionnaire with stakeholders in old building retrofitting (architects and engineers) who work as design consultants, construction managers and in construction supervisor. These 15 interviews were independent of the interviews considered in opinion survey. The questionnaire was formulated with 30 YES / NO questions type with the possibility to add comments and suggestions. The questions were related to the 22 parameters under analysis. Table 4 presents the numbering of the questions comprised in the questionnaire and the percentage of YES responses in each parameter.

About $70 \%$ of the interviewees totally agree with the contents of the 22 parameters as well as with their relevance to construction project management and the project success. The results highlight minimum percentages of YES responses for parameters P01 (40\%), P06 (66.6\%), P09 (26.7\%), P30 and P31 (53.3\%). The analysis of other questions from the questionnaire through triangulation (Yin 2005; Fellows, Liu 2008) showed the relevance of those parameters, namely P01 and P09.

\subsection{Test the hypothesis - validation and reliability}

Considering the formulated hypothesis, the study aims to assess the relevance of the whole 50 parameters and their thematic areas viewing their integration in old building retrofit projects. The results obtained from the desk review of building 
Table 4. Numbering of the interview questions, results and convergence parameters

\begin{tabular}{|c|c|c|c|}
\hline Question & \multicolumn{2}{|c|}{ "YES” response } & Parameters not tested in project designs desk review \\
\hline Q1a; Q2a & \multicolumn{2}{|c|}{$100 \% ; 40 \%$} & P01. Public transport \\
\hline $\mathrm{Q} 1 \mathrm{~b} ; \mathrm{Q} 2 \mathrm{~b}$ & \multicolumn{2}{|c|}{$100 \% ; 86.7 \%$} & P02. Car parking \\
\hline $\mathrm{Q} 1 \mathrm{c} ; \mathrm{Q} 2 \mathrm{c}$ & \multicolumn{2}{|c|}{$100 \% ; 80 \%$} & P03. Local amenities \\
\hline Q1d; Q2d & \multicolumn{2}{|c|}{$100 \% ; 66.7 \%$} & P06. Urban space quality \\
\hline Q1e; Q2e & \multicolumn{2}{|c|}{$100 \% ; 26.7 \%$} & P09. Gardens and leisure places \\
\hline Q3 & \multicolumn{2}{|l|}{$100 \%$} & P23. Novel materials \\
\hline $\mathrm{Q} 4$ & \multicolumn{2}{|l|}{$93.3 \%$} & P25. Water recovery and reuse \\
\hline \multirow[t]{2}{*}{ Q5; Q15b } & \multirow{2}{*}{\multicolumn{2}{|c|}{$53.3 \% ; 100 \%$}} & P30. Bioclimatic solutions \\
\hline & & & P31. Other sustainable solutions \\
\hline \multirow{3}{*}{$\begin{array}{l}\text { Q6; Q14b; } \\
\text { Q15a; Q15c }\end{array}$} & \multirow{3}{*}{\multicolumn{2}{|c|}{$\begin{array}{l}100 \% ; 100 \% \\
92 \% ; 100 \%\end{array}$}} & P33. Adjoining building conservation state \\
\hline & & & P34. Stabilization and consolidation of building works and of adjoining buildings \\
\hline & & & P35. Adjoining buildings waterproofing \\
\hline Q7a $\quad$ Q14b & $60 \%$ & \multirow{3}{*}{$\begin{array}{l}100 \% \\
92 \% \\
100 \%\end{array}$} & P36. Workforce \\
\hline Q7b Q15a & $93.3 \%$ & & P37. Specialized workforce and company's technical capacities \\
\hline Q7c & $93.3 \%$ & & P38. Specialized subcontract \\
\hline Q7d & \multicolumn{2}{|l|}{$93.3 \%$} & P39. Technical requirements monitoring \\
\hline $\begin{array}{l}\text { Q8; Q14b; } \\
\text { Q15a; Q15c }\end{array}$ & \multicolumn{2}{|c|}{$\begin{array}{l}80 \% ; 100 \% \\
92 \% ; 100 \%\end{array}$} & P43. Propensity to other work constraints \\
\hline Q9 & \multicolumn{2}{|l|}{$73.3 \%$} & P44. Archaeological works prospection \\
\hline Q10 & \multicolumn{2}{|l|}{$100 \%$} & P46. Needs of occupant's relocation \\
\hline Q11 & \multicolumn{2}{|l|}{$93.3 \%$} & P47. Costs of urban space works \\
\hline Q12 & \multicolumn{2}{|l|}{$100 \%$} & P49. Possibility to apply for benefits and tax incentives \\
\hline Q13 & \multicolumn{2}{|l|}{$100 \%$} & P50. Maintenance and conservation strategies \\
\hline
\end{tabular}

retrofit projects reveal that the thematic areas of 28 out of 50 parameters are attended by legal requirements and consequently they do not need any specific validation. However, the relevance of the remaining 22 parameters omitted in the project designs is assessed through the results of the interview/questionnaire. As far as validation is concerned, the test of the hypothesis enables to assess:

- Apparent validation - all the aspects described in the management system parameters tend to be taken into account in project designs, being the omitted ones considered as relevant by area experts.

- External validation - Results obtained from the projects analysed in the desk review are imposed by construction law. The results obtained from the interviews point towards unanimity in including thematic areas not imposed by construction law in the project designs.

- Internal validation - The results of the case study reveal that the contents of the management system contribute to the success in the management of old buildings retrofit works (effect).

As far as reliability is concerned, the desk review recorded over $70 \%$ of positive responses re- garding the aspects of each parameter analysed and imposed by construction law. The results obtained from the interview/questionnaire were submitted to non parametric statistical tests for nominal variables, in which distribution, variance and relation between data are independent. Such tests are used for ordinal or nominal variables, where the median as a central location measure is frequently used. The application of the Cochran $\mathrm{Q}$ test reveals that there is a significant difference between the proportion of "YES" responses and the remaining types of response obtained, with a prevalence of the "YES" kind of response. Following Tavakol and Dennick (2011), the results from the questionnaires reveal, in the internal consistency Cronbach's alpha test, a reliability of 0.643 (moderate intensity and above 0.60). However, by doing different simulations in the responses obtained, it is possible to obtain better results in the Cronbach's alpha test. If the questionnaire results had one "NO" response in questions with only "YES" responses, then the Cronbach's alpha test would reveal a result of 0.826 (very good intensity). This result is considered satisfatory by Pestana and Gageiro (2003) and allows to accept the hypothesis because all 50 parameters of the management system are considered important and suitable for application in retrofitting projects. 


\section{CONCLUSIONS}

This study has dealt with the development a management system in a toolkit formal, the aim of which is to aid in old building retrofitting works and contribute to support stakeholders' decisionmaking. The management system was submitted to an opinion survey and was considered to contain satisfactory and relevant contents that promote resources reutilization, sustainable solutions and the inversion of the use of practices typical of new construction works. The fact that each parameter enables an option ranging from "E" (less sustainable) to "A" (more sustainable) leads to the consideration of these issues both in design and in the realisation phases. Furthermore it promotes a better performance in the building occupancy phase by adopting sustainable practices.

The results of the case study have shown the relevance of the issues addressed in the 50 parameters of the management system. In the first phase of the case study, which consisted of a desk review of building retrofit project designs, the results show that the project designs analysed responded to 28 parameters, thus making them relevant for the management of this type of project. However, the documents analysed did not contain information regarding 22 of the management system parameters. The second phase of the case study (interviews guided by a questionnaire) enabled to assess the relevance of the 22 parameters omitted in the project designs. The results showed that the contents of those parameters are relevant for old buildings retrofit projects and aid in the management process of this type of works, although they are not imposed by construction laws. The interviews also reveal that there are sustainable solutions that are not well disseminated and that there is a need for more specific information related to the development of building retrofit works.

This management system in a toolkit format addresses the specificities of each building intervention, suggests practices of higher sustainability and takes into account unexpected situations which may result in increased costs, delays and other contingencies.

\section{REFERENCES}

Ahadzie, D. K.; Proverbs, D. G.; Olomolaiye, P. O. 2008. Critical success criteria for mass house building projects in developing countries, International Journal of Project Management 26(6): 675-687. https://doi.org/10.1016/j.ijproman.2007.09.006
Asadi, E.; Gameiro da Silva, M.; Antunes, C. H.; Dias, L. 2012. Multi-objective optimization for building retrofit strategies: a model and an application, Energy and Buildings 44: 81-87. https://doi.org/10.1016/j. enbuild.2011.10.016

Balin, A.; Baraçli, H. 2015. A fuzzy multi-criteria decision making methodology based upon the interval type-2 fuzzy sets for evaluating renewable energy alternatives in Turkey, Technological and Economic Development of Economy (Article in Press). https://doi.org/10.3846/20294913.2015.1056276

Balsas, C. 2004. City centre regeneration in the context of the 2001 European capital of culture in Porto, Portugal, Local Economy Journal 19(4): 396-410.

BuildingEQ. 2008. Guidelines for the evaluation of building performance, in C. Neumann; D. Jacob (Eds.). Report of Workpackage 3 of BuildingEQ. BuildingEQ project, Intelligent Energy Europe (IEE) Programme of the European Commission. Fraunhofer Institute for Solar Energy Systems, Freiburg, Germany.

Carassus, J.; Andersson, N.; Kaklauskas, A.; Lopes, J.; Manseau, A.; Ruddock, L.; de Valence, G. 2006. Moving from production to services: a built environment cluster framework, International Journal of Strategic Property Management 10(3): 169-184.

Cerreta, M.; Panaro, S.; Cannatella, D. 2012. Multidimensional spatial decision-making process: local shared values in action, in B. Murgante; O. Gervasi; S. Misra; N. Nedjah; A. M. A. C. Rocha; D. Taniar; B. O. Apduhan (Eds.). Proceedings of $12^{\text {th }}$ International Conference Computational Science and its Applications - ICCSA 2012, 18-21 June 2012, Salvador de Bahia, Brazil, Part II, Lecture Notes in Computer Science 7334: 54-70. https://doi.org/10.1007/978-3-642-31075-1

Chan, I. P. C.; Scott, D.; Lam, E. W. M. 2002. Framework of success criteria for design/build projects, Journal of Management in Engineering 18: 120-128. https:// doi.org/10.1061/(ASCE)0742-597X(2002)18:3(120)

Council of European Union. 2014. Conclusions on cultural heritage as a strategic resource for a sustainable Europe, in Education, Youth, Culture and Sport Council meeting, 20 May 2014, Brussels. OJ EU nr. 183/2014.

Dall'O, G.; Galante, A.; Pasetti, G. 2012. A methodology for evaluating the potential energy savings of retrofitting residential building stocks, Sustainable Cities and Society 4: 12-21. https://doi.org/10.1016/j. scs.2012.01.004

Decree-law 309/2009 of 23 October. Procedimento de classificação dos bens imóveis de interesse cultural, bem como o regime jurídico das zonas de protecção e do plano de pormenor de salvaguarda. Diário da República, 1. ${ }^{a}$ série - N. ${ }^{\circ} 206$ - 23 de Outubro de 2009.

Dutta, M.; Husain, Z. 2009. An application of multicriteria decision making to built heritage. The case of Calcutta, Journal of Cultural Heritage 10(2): 237243. https://doi.org/10.1016/j.culher.2008.09.007

European Commission. 2014. Communication from the Commission to the European Parliament, the Council, The European Economic and Social Committee and the Committee of the Regions. Towards an 
integrated approach to cultural heritage for Europe. Brussels, 22.7.2014, COM (2014) 477 final.

Fellows, R.; Liu, A. 2008. Research methods for construction. $3^{\text {rd }}$ ed. West Sussex: Wiley-Blackwell Publishing Ltd.

Ferreira, J.; Pinheiro, M. D.; de Brito, J. 2014. Portuguese sustainable construction assessment tools benchmarked with BREEAM and LEED: an energy analysis, Energy and Buildings 69: 451-463. https://doi.org/10.1016/j.enbuild.2013.11.039

Ferretti, V.; Bottero, M.; Mondini, G. 2014. Decision making and cultural heritage: an application of the multi-attribute value theory for the reuse of historical buildings, Journal of Cultural Heritage 15(6): 644-655. https://doi.org/10.1016/j.culher.2013.12.007

Geoghegan, L.; Dulewicz, V. 2008. Do project managers' leadership competencies contribute to project success?, Project Management Journal 39(4): 58-67. https://doi.org/10.1002/pmj.20084

Gudienè, N.; Banaitis, A.; Banaitienè, N.; Lopes, J. 2013. Development of a conceptual critical success factors model for construction projects: a case of Lithuania, Procedia Engineering 57: 392-397. https://doi.org/10.1016/j.proeng.2013.04.051

Gudienè, N.; Banaitis, A.; Podvezko, V.; Banaitienė, N. 2014. Identification and evaluation of the critical success factors for construction projects in Lithuania: AHP approach, Journal of Civil Engineering and Management 20(3): 350-359. https://doi.org/10.3846/13923730.2014.914082

Hair, J. F.; Barin, B.; Money, A. H.; Samouel, P. 2003. Fundamentos de métodos de pesquisa em adminis. tração. Bookman.

Hatush, Z.; Skitmore, M. 1997. Criteria for contractor selection, Construction Management and Economics 15(1): 19-38.

https://doi.org/10.1080/014461997373088

Henriques, C. O.; Coelho, D. H.; Antunes, C. H. 2015. A multi-objective input-output model to assess E4 impacts of building retrofitting measures to improve energy efficiency, Technological and Economic Development of Economy 21(3): 483-494.

https://doi.org/10.3846/20294913.2015.1015065

ICOMOS. 2003. Principles for the analysis, conservation and structural restoration of architectural heritage. International Council on Monuments and Sites ICOMOS.

Iwaro, J.; Mwasha, A.; Williams, Rupert G.; Zico, R. 2014. An integrated criteria weighting framework for the sustainable performance assessment and design of building envelope, Renewable and Sustainable Energy Reviews 29: 417-434. https://doi.org/10.1016/j. rser.2013.08.096

Jensen, P. A.; Maslesa, E. 2015. Value based building renovation - a tool for decision-making and evaluation, Building and Environment 92: 1-9. https://doi.org/10.1016/j.buildenv.2015.04.008

Jha, K. N.; Iyer, K. C. 2006. Critical factors affecting quality performance in construction projects, Total Quality Management 17(9): 1155-1170. https://doi.org/10.1080/14783360600750444
Koskela, L.; Ballard, G.; Howell, G.; Tommelein, I. 2002. The foundations of lean construction, in R. Best; G. de Valence (Eds.). Design and construction: building in value. Butterworth-Heinemann, Oxford, UK, 211-226.

Lewis, P.; Shan, Y.; Hazzard, E. 2015. Sustainability planning framework for reducing ground-level ozone formation in construction activities, Procedia Engineering 118: 766-773. https://doi.org/10.1016/j.proeng.2015.08.512

Ma, Z.; Cooper, P.; Daly, D.; Ledo, L. 2012. Existing building retrofits: methodology and state-of-the-art, Energy and Buildings 55: 889-902. https://doi.org/10.1016/j.enbuild.2012.08.018

Mahmood, S.; Shahrukh, K.; Sajid, A. 2012. Identification of critical success factors for reduction of cost of poor quality from the construction projects, in Third International Conference on Construction in Developing Countries (ICCIDC-III) Advancing in Civil and Architectural Construction Engineering \& Management, 4-6 July 2012, Bangkok, Thailand.

Marco, A. D.; Thaheem, M. J. 2014. Risk analysis in construction projects: a practical selection methodology, American Journal of Applied Sciences 11(1): 74-84. https://doi.org/10.3844/ajassp.2014.74.84

Mazzanti, M. 2002. Cultural heritage as multi-dimensional, multi-value and multi-attribute economic good: toward a new framework for economic analysis and valuation, The Journal of Socio-Economics 31(5): 529-558. https://doi.org/10.1016/S1053$5357(02) 00133-6$

Mazzarella, L. 2015. Energy retrofit of historic and existing buildings. The legislative and regulatory point of view, Energy and Buildings 95: 23-31. https://doi.org/10.1016/j.enbuild.2014.10.073

Medineckiene, M.; Zavadskas, E. K.; Björk, F.; Turskis, Z. 2015. Original research article: multi-criteria decision-making system for sustainable building assessment/certification, Archives of Civil and Mechanical Engineering 15(1): 11-18. https://doi. org/10.1016/j.acme.2014.09.001

Menassa, C. 2011. Evaluating sustainable retrofits in existing buildings under uncertainty, Energy and Buildings 43(12): 3576-3583. https://doi.org/10.1016/j.enbuild.2011.09.030

Morelli, M.; Harrestrup, M.; Svendsen, S. 2014. Method for a component-based economic optimisation in design of whole building renovation versus demolishing and rebuilding, Energy Policy 65: 305-314. https://doi.org/10.1016/j.enpol.2013.09.068

Mulliner, E.; Smallbone, K.; Maliene, V. 2013. An assessment of sustainable housing affordability using a multiple criteria decision making method, Omega 41(2): 270-279. https://doi.org/10.1016/j.omega.2012.05.002

Niu, J.-M.; Lechler, T. G.; Jiang, J.-L. 2010. Success criteria framework for real estate project, Management Science and Engineering 4(3): 10-23.

Ochoa, C. E.; Capeluto, I. G. 2015. Decision methodology for the development of an expert system applied in an adaptable energy retrofit façade system for resi- 
dential buildings, Renewable Energy 78: 498-508. https://doi.org/10.1016/j.renene.2015.01.036

Olander, S.; Landin, A. 2005. Evaluation of stakeholder influence in the implementation of construction projects, International Journal of Project Management 23: 321-328. https://doi.org/10.1016/j.ijproman.2005.02.002

Oliveira, R. A. F. 2013. Metodologia de gestão de obras de reabilitação em centros urbanos históricos. Unpublised PhD Thesis. FEUP, Porto (in Portuguese).

Østergård, T.; Jensen, R. L.; Maagaard, S. E. 2016. Building simulations supporting decision making in early design - a review, Renewable and Sustainable Energy Reviews 61: 187-201. https://doi.org/10.1016/j. rser.2016.03.045

Parfitt, M.; Sanvido, V. 1993. Checklist of critical success factors for building projects, Journal of Management in Engineering 9(3): 243-249. https://doi.org/10.1061/ (ASCE)9742-597X(1993)9:3(243)

Pestana, M. H.; Gageiro, J. 2003. Análise de dados para ciências sociais: a complementaridade do SPSS $3^{\mathrm{a}}$ ed. Lisboa: Sílabo.

Pickard, R. 2001. Management of historic centres (conservation of the European built heritage series). London: Taylor\&Francis.

Rosenfeld, Y.; Shohet, I. M. 1999. Decision support model for semi-automated selection of renovation alternatives, Automation in Construction 8(4): 503-510. https://doi.org/10.1016/S0926-5805(98)00097-1

Russell-Smith, S. V.; Lepech, D. 2015. Cradle-to-gate sustainable target value design: integrating life cycle assessment and construction management for buildings, Journal of Cleaner Production 100: 107-115. https://doi.org/10.1016/j.jclepro.2015.03.044

Sdei, A.; Gloriant, F.; Tittelein, P.; Lassue, S.; Hanna, P.; Beslay, C.; Gournet, R.; McEvoy, M. 2015. Social housing retrofit strategies in England and France: a parametric and behavioural analysis, Energy Research \& Social Science 10: 62-71. https://doi.org/10.1016/j.erss.2015.07.001
Sorace, S.; Terenzi, G. 2013. Structural assessment of a modern heritage building, Engineering Structures 49: 743-755. https://doi.org/10.1016/j.engstruct.2012.12.012

Srdić, A.; Šelih, J. 2011. Integrated quality and sustainability assessment in construction: a conceptual model, Technological and Economic Development of Economy 17(4): 611-626. https://doi.org/10.3846/202 94913.2011.603177

Tavakol, M.; Dennick, R. 2011. Making sense of Cronbach's alpha, International Journal of Medical Education 2: 53-55. https://doi.org/10.5116/ijme.4dfb.8dfd

Thabrew, L.; Wiek, A.; Ries, R. 2009. Environmental decision making in multi-stakeholder contexts: applicability of life cycle thinking in development planning and implementation, Journal of Cleaner Production 17(1): 67-76. https://doi.org/10.1016/j. jclepro.2008.03.008

Todd, J. A.; Crawley, D.; Geissler, S.; Lindsey, G. 2001. Comparative assessment of environmental performance tools and the role of the Green Building Challenge, Building Research and Information 29(5): 325-335. https://doi.org/10.1080/09613210110064268

UNESCO. 2014. Developing historic cities. Keys for understanding and taking action. A compilation of case studies on the conservation and management of historic cities. UNESCO World Heritage Centre, France-UNESCO Cooperation Agreement.

Volvačiovas, R.; Turskis, Z.; Aviža, D.; Mikštienè, R. 2013. Multi-attribute selection of public buildings retrofits strategy, Procedia Engineering 57: 12361241. https://doi.org/10.1016/j.proeng.2013.04.156

Walker, A. 2007. Project management in construction. Oxford: Blackwell Science.

Wang, H.-J.; Zeng, Z.-T. 2010. A multi-objective decisionmaking process for reuse selection of historic buildings, Expert Systems with Applications 37(2): 12411249. https://doi.org/10.1016/j.eswa.2009.06.034

Yin, R. K. 2005. Case study research: design and methods. Thousand Oaks: Sage Publications. 